\title{
集成材に埋め込んだ樹脂カプセ PULL-OUT TESTS OF GLUE CAPSULE ルアンカーの引き抜き実験 ANCHOR EMBEDED IN GLUED LAMINATED LUMBER
}

信澤宏由 一 - *1 定方 啓 —

キーワード :

樹脂カプセルアンカー, 引抜き耐力, 付着面積, 集成材, ボルト引張強度, 穿 孔寸法

Keywords

Glue capsule anchor, Pull-out strength, Bore hole diameter, Glued laminated lumber, Adhesive area, Tensile strength of bolt

\section{Hiroyoshi NOBUSAWA $-* 1 \quad$ Kei SADAKATA $-* 2$}

This paper is concerned with uses of chemical anchor for the glued laminated lumber. The anchor bolt is fixed in the base material by using capsules filled with an adhesive. A newly developed two liquid type adhesive was used. The variables in this research are the bolt diameter, length of anchorage and anisotropy of glued laminated lumber. The proof strength and destruction mechanism of this system have been clarified and emipirical formulas proposed. These results are to be applied to the large beam to column joint and the column to base joint.

\section{1.はじめに}

木質構造の設計において、柱一梁接合部や柱脚部の接合方法は最 も重要な部分である。本研究はこれまでコンクリートメーソンリー やコンクリート構造物の改修、載強等に使用されている、あと施工 アンカーを木質構造に適用することで、接合部の耐力および施工の 迅速性、確実性を増す方法を研究したものである。過去の研究で、 樹脂カプセルアンカーを集成材に適応し、その可能性を得ることか 出来た。1)，2；本研究は、それを更に発展させ、集成材に樹脂カプ セルアンカーを使用した場合のボルト径、アンカー埋め込み長さ、 集成材への方向性等の因子変動による预力、破壊機構を実験によっ て明確にし、栖力算定式を提案するものである。

\section{2. 引抜き試験概要}

\section{1 樹脂カプセルアンカー}

見在、あと施工アンカーは、金属㹡張系アンカーと接着系アンカ 一とに大別される ${ }^{3)}$ が、本実験で採用したアンカーは、木質構造へ の支持耐力の信頼性および施工性能の良さから、接着系アンカーの 一種である樹脂カプセルアンカーを使用した。その形状は図 1 に示 す。これは、管状ガラス管にビスフェノール系不餲和ボリェステル 樹脂、硬化郕および焼成骨材を収容しカプセル状にしたもので、上 記二種類の接着㓣を混合することでアンカーボルトを母材内に固着 するシステムである。

その施工方法は、ボルト孔の穿孔、清挶およびカプセル挿入後、 ボルトによる掜拌を行うことで、二つの接着郕および焼成骨材で硬 化させるものである。樹脂カプセル施工方法を図 2 に示した。アン

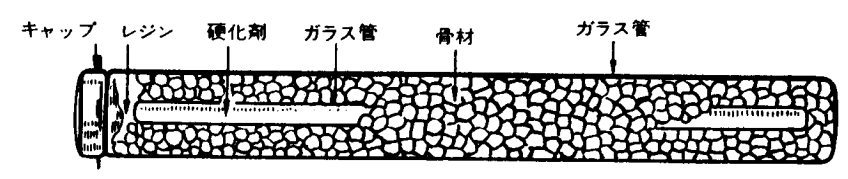

図1樹脂カプセルの形状
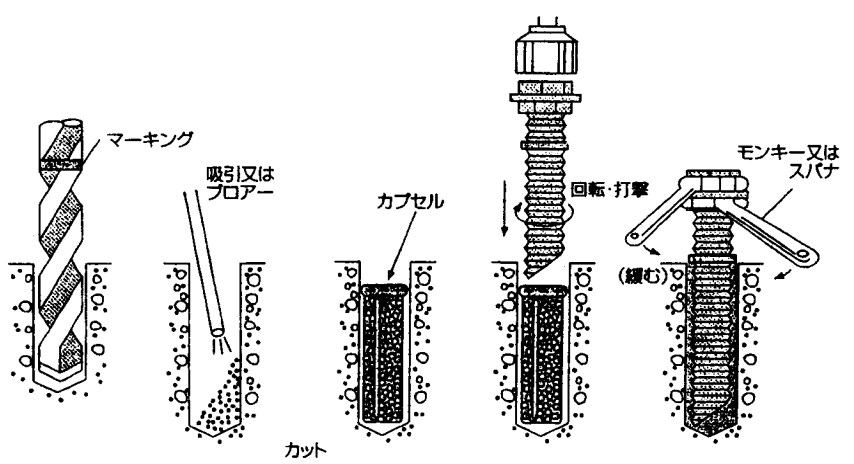

1. 穿孔 かット

図2樹脂カプセルの施工方法

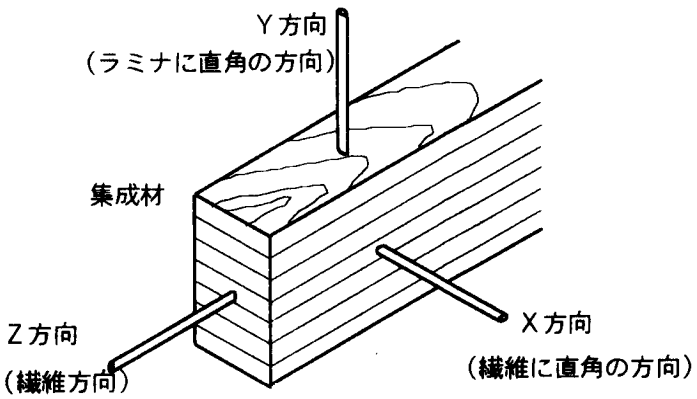

図3アアンカー埋め込み方向

*1 前橋工科大学 教授. 工博

(下371-0816 前橋市上佐鳥町460)

*2 前橋工科大学 教授. 工博

\section{*1 Prof., Maebashi Institute of Tech., Dr. Eng.}

*2 Prof., Maebashi Institute of Tech., Dr. Eng. 


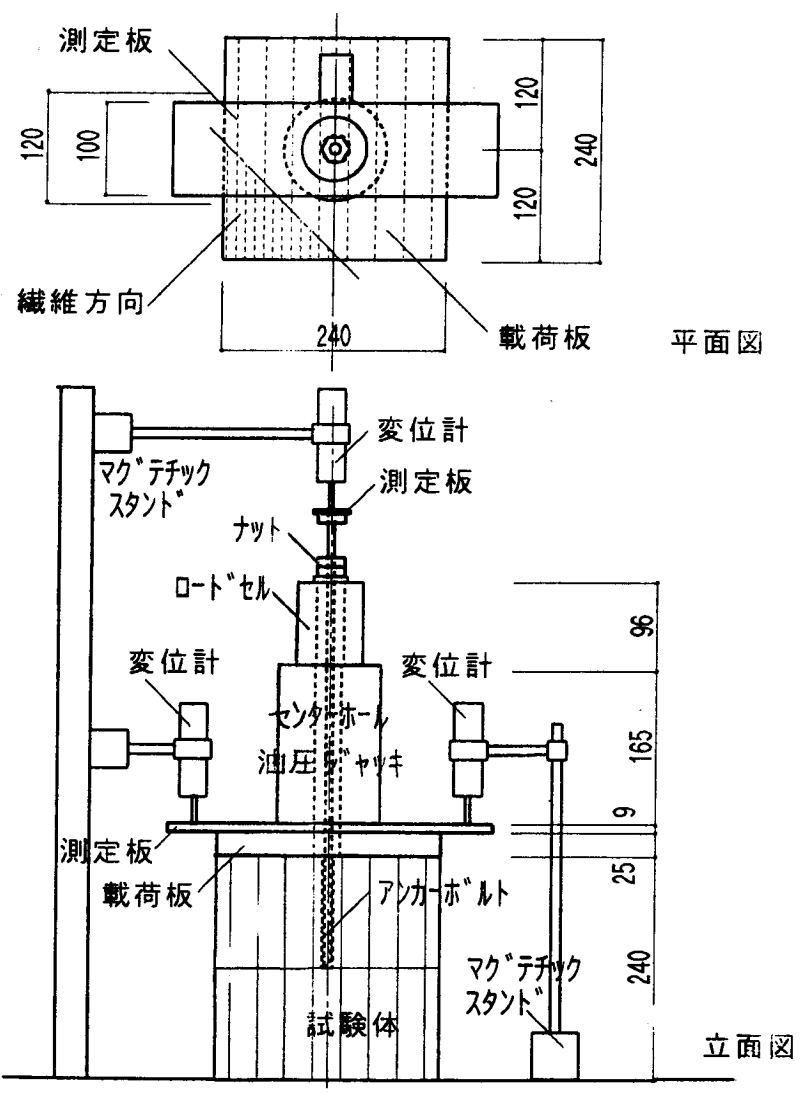

図4引抜き試験装置

カー箭の先端形状は施工性の良さから $45^{\circ}$ カットを使用した。ま た、集成材への食い込み効果を期待し、樹脂に反応する硬化郕に焼 成骨材加えるタイプの樹脂カプセルアンカーを使用した。

\section{表 1 試験体仕様及び試験結果}

\section{2 試験体}

試験体の仕样および試験体名を表 1 に示す。実験したボルトはM 12，M16の他に、過去の実験結果に連続性をもたせるためにM10の 実験も行った。ボルトのアンカー長さは最近の傾向からボルト径の 5 倍 $(5 \mathrm{~d}) 、 10$ 倍 $(10 \mathrm{~d}) 、 15$ 倍（15d）とし、集成材に異方性 があることから、それによる影㞰を謂へるために、図３に示すよう に織維に直角の方向（X方向）、ラミナに直角の方向（Y方向）、 轾維方向 (Z方向) とし、これら 3 方向について央験を行った。さ らに、試験值のばらつきを考慮して、同じ条件の試験体をそれぞれ 3㑭づつ行うこととした。

採用した樹脂カプセルアンカーのカプセルの寸法は、使用するア ンカーボルトと理め込み深さによって異なり、それらの寸法も表 1 に示した。ボルトは全ねじボルトを使用し、ボルトの先端は、カプ セルの摜找が十分に行われるように $45^{\circ}$ にカットした。ボルトの材 質はSS400を使用し、引張強度はM10が $3,158 \mathrm{~kg} \mathrm{f}(322 \mathrm{~N}) 、 \mathrm{M} 12$ が 4,55 $6 \mathrm{kgf}$ (465N)、M16が9431kgf (962N)である。試験体母材はベイマッ集 成材でラミナ厚 $35 \mathrm{~mm}$ 、断面寸法 $120 \mathrm{~mm} \times 240 \mathrm{~mm}$ の柱材を用いた。含水 率は約 $13 \%$ 、王縮強度（䋞維方向）は、 $568 \mathrm{kgf} / \mathrm{cm}^{2}\left(55.7 \mathrm{~N} / \mathrm{mm}^{2}\right)$ で ある。なお、Z方向の試験体については、上記柱材を約 $24 \mathrm{~cm} に$ 切断 したものを試験体とし、一つの断面に一本ずつボルトを埋め込み、 その他の方向については $1 \mathrm{~m}$ の試験体に $30 \mathrm{~cm}$ 間隔でボルトを埋め込ん だ。

\section{3 施工方法}

施工方法は、図 1 に示した。施工手順は以下の通りで、鉄筋コン クリート用に定められた方法に準じて行った。(1)母材（集成材）に 所定の寸法の穿孔を行う。(2)孔内の切りくずを取り除く。(3)所定の 樹脂カプセルを孔内に挿入する。(4)ボルトを電動ドリルに取り付け

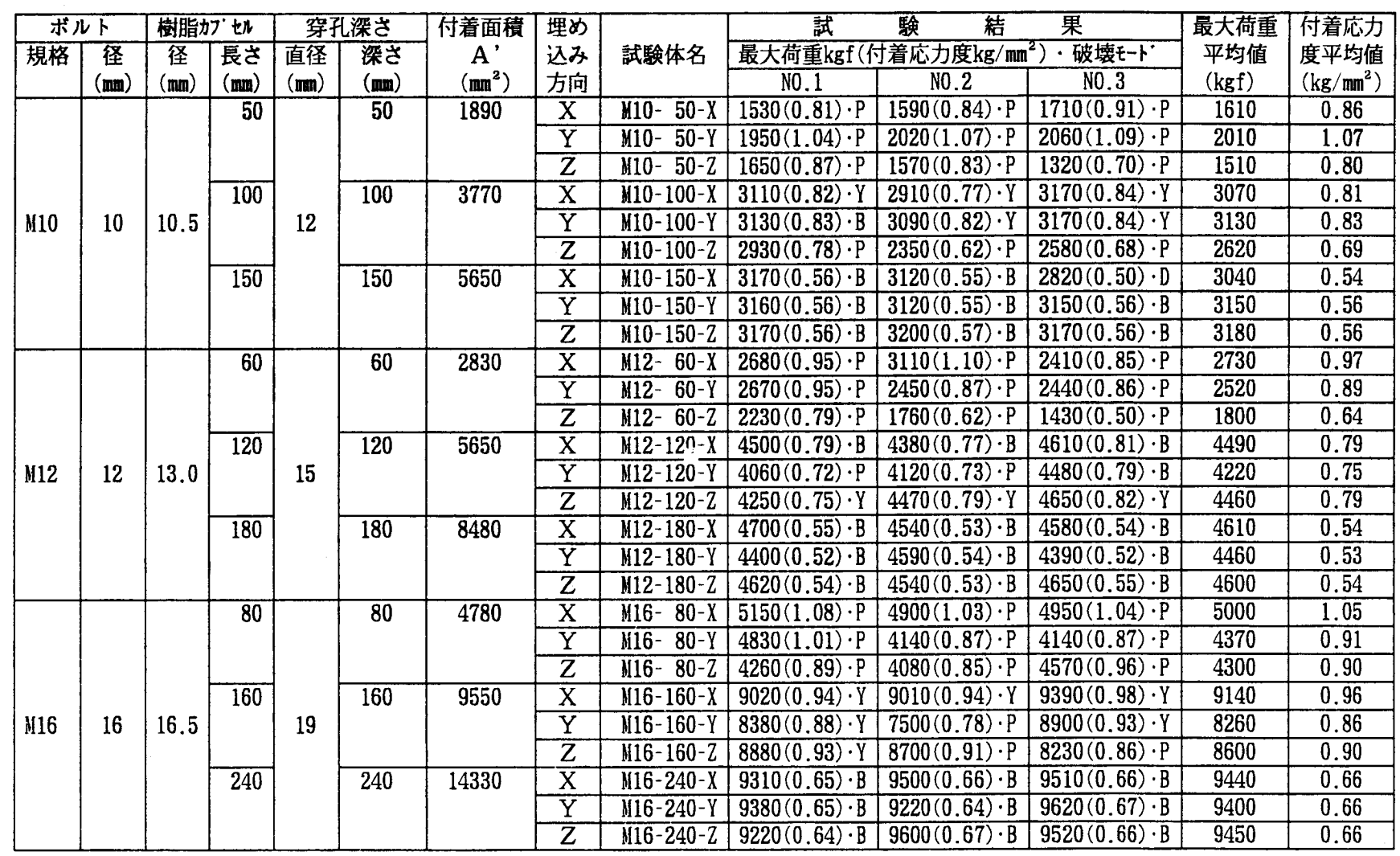


カプセルを摫拌、混合しながら孔の底まで埋め込む。(5)所定の時間 養生する。なお、樹脂アンカーは 30 分程度で硬化するが、アンカ 一強度の信頼性を増すために原則として 1 日経過後、試験した。

\section{4 試験方法}

試験は、図 3 に示す試験装置で行った。荷重の測定はロードセル でおこない変位の測定は、ボルトの引抜き量を測定する電気式変位 計を図のようにボルトの先端に取り付けた。載荷プログラムは、 方向単調加力とした。なお、試験装置の母材へのめり込み量を载加 板に取り付けた 2 個の変位計で計測し、その相加平均值と試験体か らロードセル上端までのボルトの伸びを補正し、引抜き量とした。

\section{3. 試験結果と考察}

\section{1 試験結果}

表 1 に各試験体の試験結果を示す。表 1 および図 $5 \sim 7$ の試験体 名の記号は、ボルト径-アンカー長さ $(\mathrm{mm})$ - 集成材に対するボル トの方向を示す。あと施エアンカーの引き抜き試験の破壊モードは、 ボルトの抜け出し、ボルトの引張破断、ボルト降伏後のボルト抜け 出しのいずかとなるが、ボルトの抜け出し破壊がボルトの引張破壊 に変化する点を引拢き分岥点と名づける。

引き抜き試験破壊モードの記号はそれぞれ、P：ボルトの抜け出 し、B：ボルトの引張破断、 $\mathrm{Y}:$ : ボルト降伏後のボルト抜け出し、 $\mathrm{D}$ ：施工不良、接着不良を示す。試験体の各グループごとの代表的 なP $-\Delta$ 曲線を図 5 〜 示す。
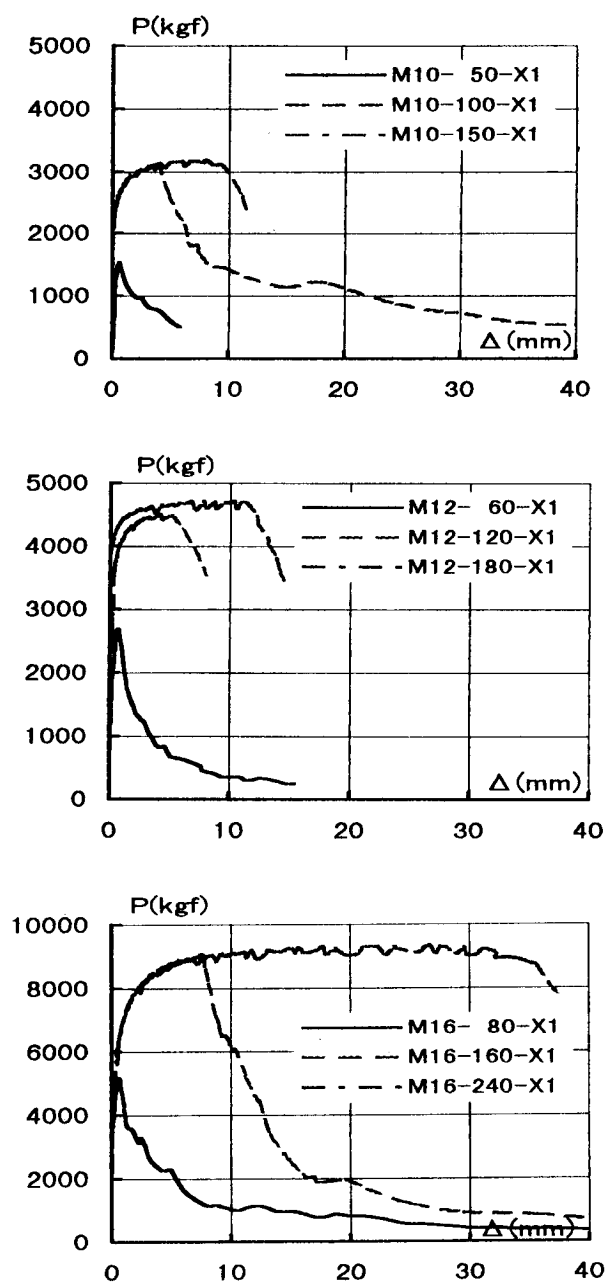

$\mathrm{X} 、 \mathrm{Y} 、 \mathrm{Z}$ 方向、いずれのアンカーボルトの埋め込み方向、ボル ト径においても、アンカー長さが $5 \mathrm{~d}$ 場合は、ボルトの抜け出し破 壊、 $15 \mathrm{~d}$ ではボルトの引張破断による崩壊であった。また、Z方向

（紻維方向）は、他の 2 方向に比べ引抜き分岐点以下では、最大甪 力後急激に強度が低下している。アンカー長さが $10 \mathrm{~d}$ 場合は、アン カーボルトの埋め込み方向、ボルト径で様々な破壊モードを示して おり、それぞれの破壊モードの境界值の様相を呈している。

\section{2 考察}

表 1 より、いずれのアンカーボルトの方向、ボルト经においても アンカー長さが $5 \mathrm{~d}$ では、ボルトの抜け出し破壊、 $15 \mathrm{~d}$ では、ボル トの引っ張りによる破断である。すなわち、アンカーの十分な埋め 込み深さと適切な樹脂容量があればボルトが引張強度に達しても埋 め込み部が抜け出さないことが確認された。

図 8〜10にアンカーの付着面積之引抜き強度の関係をアンカーの 埋め込み方向別に示す。引抜き分岐点以下の付着面積と引抜き強度 の関係を回㷌分析により求め関係式を以下に示した。ただし、これ らの式適用には集成材の緎維方向の厌繀強度か、、 $568 \mathrm{kgf} / \mathrm{cm}^{2}(55.7 \mathrm{~N}$ $\left./ \mathrm{mm}^{2}\right)$ 以上必要である。

なお、関係式において
$\mathrm{y}$ ：引き拔き強度 $(\mathrm{kgf})$
$X$ ：付着面積 $\left(\mathrm{mm}^{2}\right)$
$\mathrm{R}$ ：回㱕分析における重相関係数の值
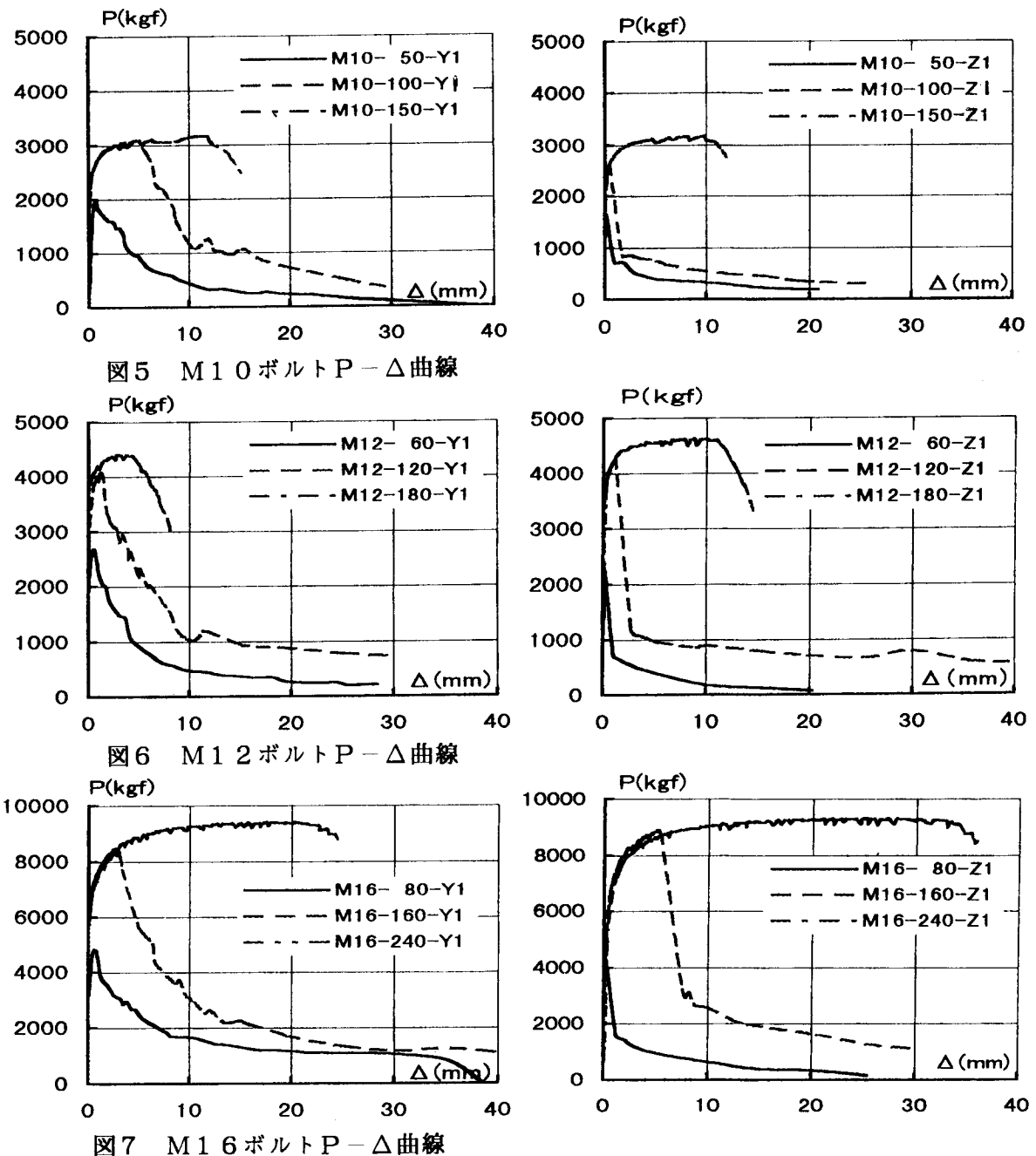


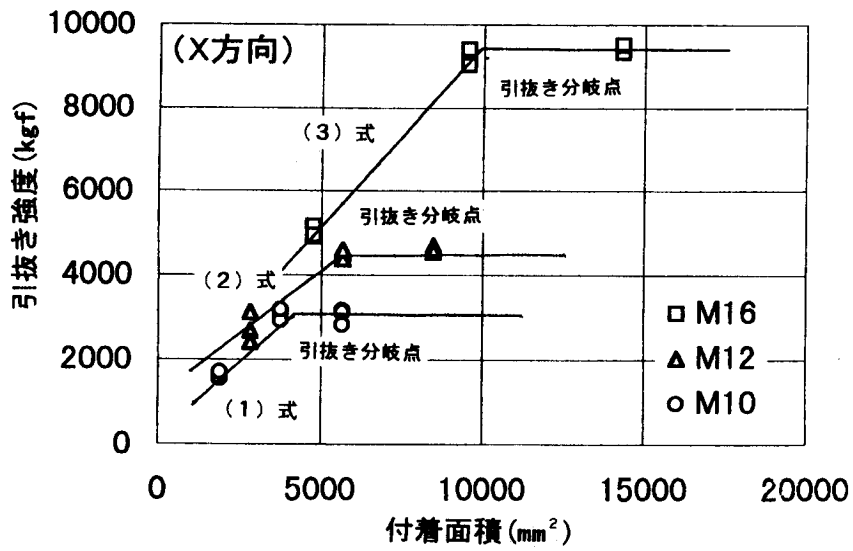

図8 X方向付着面積と引抜き強度

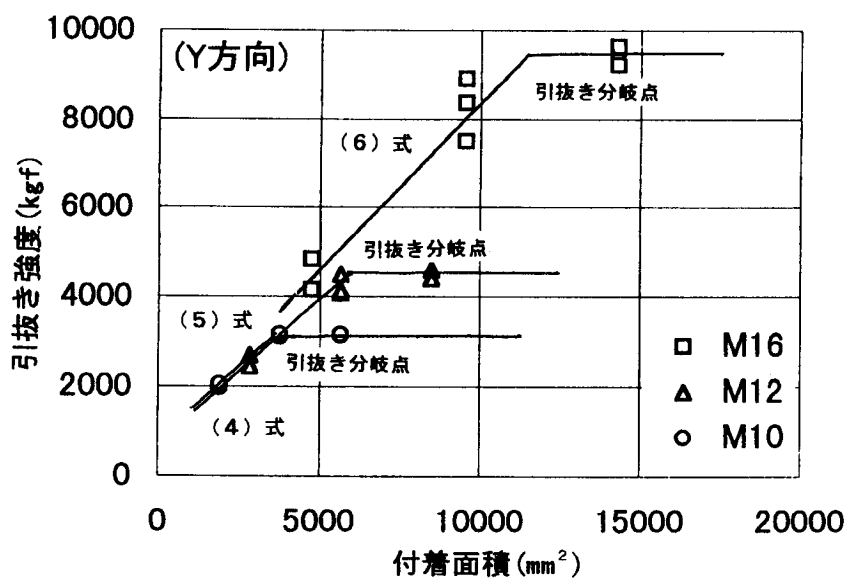

図9Y方向付着面積と引抜き強度

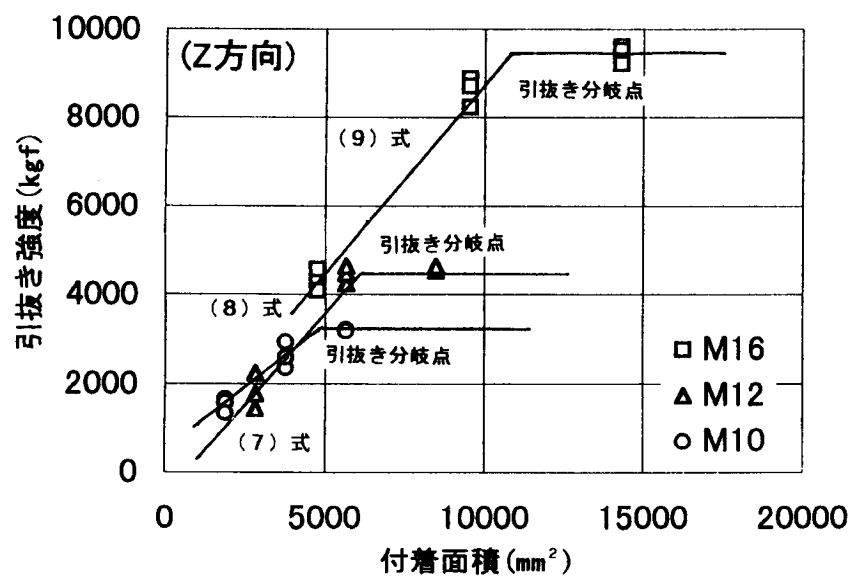

図10 Z方向付着面積と引抜き強度

M10～M16は、使用するボルトの直径を示す。

\begin{tabular}{|c|c|c|c|}
\hline \multirow[t]{3}{*}{ X方向 } & M10 & $y=0.772 x+158$ & $(R=0.992) \cdots \cdots(1)$ \\
\hline & M12 & $y=0.622 x+976$ & $(\mathrm{R}=0.971) \cdots(2)$ \\
\hline & M16 & $y=0.867 x+860$ & $(\mathrm{R}=0.997) \cdots(3)$ \\
\hline \multirow[t]{3}{*}{ Y方向 } & M10 & $y=0.594 x+892$ & $(\mathrm{R}=0.998) \cdots(4)$ \\
\hline & M12 & $y=0.600 x+827$ & $(R=0.984) \cdots(5)$ \\
\hline & M16 & $y=0.814 x+480$ & $(R=0.972) \cdots(6)$ \\
\hline \multirow[t]{3}{*}{ Z方向 } & M10 & $y=0.587 x+404$ & $(\mathrm{R}=0.943) \cdots(7)$ \\
\hline & M12 & $y=0.937 x-844$ & $(R=0.981) \cdots(8)$ \\
\hline & M16 & $y=0.901 x-0.333$ & $(\mathrm{R}=0.994) \cdots(9)$ \\
\hline
\end{tabular}

これらのグラフは、図8〜10に示した。

今回の実験では、回㷌分析における重相関係数の值は良好な結果 が得られた。

アンカーが何 $\mathrm{d}$ を限度にその分岐点に達するかを上記 $(1) \sim(9) に$ より算定すると、X方向は10.2d〜10.4d、Y方向は10.0d〜11.5d、

$Z$ 方向は $10.2 \mathrm{~d} \sim 12.9 \mathrm{~d}$ となった。

図8〜10において同じ付着面積に対して直径が大きい方が引抜き 期力が大きい。これは引抜き強度が引っ張り力によりボルト径が減 少することで耐力が決定してくることにその要因があると考えられ る。今回の実験でM12は、予測したよりも耐力が得られなかったが これは樹脂容量が影響しているものと考えられる。

ボルト径に対する適切な樹脂容量を検討するために、引抜き分岐

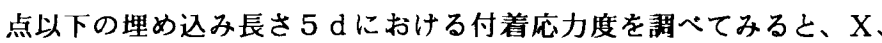
$Y 、 Z 3$ 方向の平均で穿孔值径/ボルト径の比が $5 \%$ 娍少で $15 \%$ の 付着強度の上昇が認められた。今回の実験ではM12が穿孔直径/ボ ルト径の比が大きかったために、一部耐力低下を生じたものと推測 される。

これら㴻脂カプセルアンカーを使って先行して実施した梁接合部、 柱梁接合部、壁脚部の実験 (2)において、いずれも十分な引抜き耐力 が得られている。

4.まとめ

本研究で分かったことをまとめると次のようになる。

(1) ボルトの埋め込み長さがM10（引張強度 $3,158 \mathrm{kgf}$ ）で $11 \mathrm{~d}$ 以上、 $\mathrm{M} 12$ (引張強度 $4,556 \mathrm{kgf}$ ) で $12 \mathrm{~d}$ 以上、M16（引張強度 $9,431 \mathrm{kgf}$ ) で $13 \mathrm{~d}$ 以上あれば終局引抜き耐力はボルトの引張強度となる。

(2) 引き抜き分忮点までは、ボルト引張による抜けだし破壊であり 埋め込み長さを増せば引抜き耐力は上昇する。

(3) 集成材の䋞維方向の圧䋨強度、 $568 \mathrm{kgf} / \mathrm{cm}^{2}\left(55.7 \mathrm{~N} / \mathrm{mm}^{2}\right)$ 以上の材 に対し引き抜き分忮点以下における引き抜き強度実験式を示した。

(4) 集成材のもつ異方性の引き抜き耐力への影謷は、分岐点以下の 場合絩維方向の涌力が他の 2 方向に比べやや耐力が小さく、最大 強度後の強度低下が激しかった。

\section{5.あとがき}

従来より太いアンカーボルトの使用および改良された樹脂カプセ ルアンカーの集成材構造への利用でボルトが引張強度に達しても埋 め込み部が抜け出さない好結果が得られた。最後に、研究に際し試 験体および製作を株式会社吉原社長吉原俊男氏に、樹脂カプセルア ンカーを日本デコラックス株式会社（部長、丹羽亮氏）に提供して いただいた。ここに心から謝意を表します。

\section{參考文献}

1）定方啓、山田康成、朝山和住、丹羽 亮、松下武殸：集成材を用いた 柱一梁接合部における耐力と履歴特性について（その2）樹脂アンカ の引抜試験と柱 - 梁接合部実験)、日本建築学会東海支部研究報告pp. $209 \sim 212,1989.2$

2) H.Nobusawa, K.sadakata: Glue-Capsule Anchor Technique to The Metal Box Type Beam to Column Joint, Proceeding of 5th Horld Conference on Timber Engineering pp.840 841, 1998.8

3）広沢雅也、松崎育宏：あと施工アンカー設計・施工読本一初歩から応 用まで一、建築技術, 1991.12

[1998年10月20日原稿受理 1999年 2 月 8 日採用決定］ 